\title{
The clinical Pseudomonas fluorescens MFN1032 strain exerts a cytotoxic effect on epithelial intestinal cells and induces Interleukin-8 via the AP-1 signaling pathway
}

Amar Madi ${ }^{1}$, Omar Lakhdari ${ }^{3}$, Hervé M Blottière ${ }^{3}$, Muriel Guyard-Nicodème ${ }^{1}$, Karine Le Roux ${ }^{3}$, Anne Groboillot ${ }^{1}$, Pascal Svinareff ${ }^{2}$, Joel Doré ${ }^{3}$, Nicole Orange ${ }^{1}$, Marc GJ Feuilloley ${ }^{1}$, Nathalie Connil ${ }^{1 *}$

\begin{abstract}
Background: Pseudomonas fluorescens is present in low number in the intestinal lumen and has been proposed to play a role in Crohn's disease (CD). Indeed, a highly specific antigen, I2, has been detected in CD patients and correlated to the severity of the disease. We aimed to determine whether $P$. fluorescens was able to adhere to human intestinal epithelial cells (IECS), induce cytotoxicity and activate a proinflammatory response.

Results: Behaviour of the clinical strain $P$. fluorescens MFN1032 was compared to that of the psychrotrophic strain $P$. fluorescens MF37 and the opportunistic pathogen P. aeruginosa PAO1. Both strains of $P$. fluorescens were found to adhere on Caco-2/TC7 and HT-29 cells. Their cytotoxicity towards these two cell lines determined by LDH release assays was dose-dependent and higher for the clinical strain MFN1032 than for MF37 but lower than $P$. aeruginosa PAO1. The two strains of $P$. fluorescens also induced IL-8 secretion by Caco-2/TC7 and HT-29 cells via the AP-1 signaling pathway whereas $P$. aeruginosa PAO1 potentially used the NF- $\kappa$ B pathway.

Conclusions: The present work shows, for the first time, that $P$. fluorescens MFN1032 is able to adhere to IECs, exert cytotoxic effects and induce a proinflammatory reaction. Our results are consistent with a possible contribution of $P$. fluorescens in CD and could explain the presence of specific antibodies against this bacterium in the blood of patients.
\end{abstract}

\section{Background}

Pseudomonas aeruginosa is an opportunistic pathogen frequently emerging from the mucosa-associated intestinal microbiota, which can cause severe septicemia in immuno-compromised hosts. Several interaction mechanisms of $P$. aeruginosa with intestinal epithelial cells (IECs), especially adhesion and penetration, have been studied in detail [1-3]. Conversely, little attention has been given to other species of the same genus, like Pseudomonas fluorescens.

Pseudomonas fluorescens has long been considered as a psychrotrophic microorganism, unable to grow at temperatures over $32^{\circ} \mathrm{C}$, however we have recently shown

\footnotetext{
* Correspondence: nathalie.connil@univ-rouen.fr

'LMDF-SME, Laboratoire de Microbiologie du Froid-Signaux et Micro-

Environnement, UPRES EA 4312, 55 rue Saint Germain, 27000 Evreux, France Full list of author information is available at the end of the article
}

that some strains isolated from a clinical environment are able to grow at or above $37^{\circ} \mathrm{C}$ [4]. P. fluorescens is a widespread gram-negative bacterium present in a variety of ecological niches such as refrigerated food products, soil, water [5] and in the digestive tract [6]. Interestingly, a highly specific antigen of $P$. fluorescens, designated as I2, was detected in the serum of $54 \%$ of the patients suffering from ileal Crohn's disease (CD) [7] and a direct link between the severity of the pathology and the level of circulating I2 antigen has been demonstrated [8]. Surprisingly, the proinflammatory potential of this bacterium or its interaction with the intestinal epithelium has never been investigated.

Several studies have focused on the mucosal immune response to pathogenic bacteria. Human IECs infected with pathogenic bacteria generally produce proinflammatory cytokines, such as interleukin (IL)-8 [9]. The
() Biomed Central

(c) 2010 Madi et al; licensee BioMed Central Ltd. This is an Open Access article distributed under the terms of the Creative Commons Attribution License (http://creativecommons.org/licenses/by/2.0), which permits unrestricted use, distribution, and reproduction in any medium, provided the original work is properly cited. 
latter has a chemotactic role and can recruit polymorphonuclear cells into the infected site and promote their infiltration of the epithelial layer infected by invasive or noninvasive bacteria $[10,11]$. IL-8 gene expression is regulated by two major transcriptional factors: nuclear factor kappa B (NF- $\kappa \mathrm{B})$ and activator protein (AP)-1 [12]. NF- $\kappa B$ has a pivotal role in the immune and inflammatory response, but also controls cell survival, proliferation and differentiation [13,14]. Recent works demonstrated that NF- $\kappa \mathrm{B}$ signaling is a critical element of the homeostatic immuno-inflammatory function in the gut. Indeed, epithelial NF- $\kappa \mathrm{B}$ preserves the integrity of the gut epithelial barrier and coordinates the antimicrobial actions of the innate and adaptive immune systems [15]. Nevertheless, hyperactivation of this transcription factor results in chronic inflammatory bowel diseases [16]. Activation of AP-1 is dependent on mitogen-activated protein kinases (MAPK) that are central in many physiological processes, including regulation of cytokine and stress responses and cytoskeletal reorganization $[17,18]$.

P. fluorescens MFN1032 is a clinical strain recently isolated in our laboratory [19]. It displays hemolytic activity toward sheep erythrocytes $[20,21]$, however, its infectious potential on human IECs is still unknown.

In the present study, we investigated adhesion and cytotoxic properties of $P$. fluorescens MFN1032 on Caco-2/TC7 and HT-29 cell lines in comparison to the psychrotrophic strain, $P$. fluorescens MF37 and the wellknown opportunist pathogen $P$. aeruginosa PAO1. The proinflammatory potential of $P$. fluorescens MFN1032 was also evaluated by the measurement of IL- 8 secretion on both Caco-2/TC7 and HT-29 cells, and analysis of $\mathrm{NF}-\kappa \mathrm{B}$ and $\mathrm{AP}-1$ activation using the reporter gene strategy.

\section{Results}

\section{Adhesion to intestinal epithelial cells}

The binding index of the clinical strain P. fluorescens MFN1032 on Caco-2/TC7 and HT-29 cells was determined after $5 \mathrm{~h}$ of incubation and compared to $P$. fluorescens MF37 and $P$. aeruginosa PAO1. The data presented in Figure 1 show that these bacterial strains adhere to both cell lines but the binding index was higher for Caco-2/TC7 (Figure 1A) than for HT-29 (Figure 1B).

$P$. aeruginosa $\mathrm{PAO} 1$ showed the highest adhesion potential on Caco-2/TC7 cells compared to P. fluorescens MF37 and P. fluorescens MFN1032. When the cells were infected with a $10^{6} \mathrm{CFU}$ or $10^{8} \mathrm{CFU} \mathrm{ml}{ }^{-1}$ bacterial solution, the mean adhesion index of $P$. aeruginosa PAO1 reached $12.6 \pm 2.6$ or $32.1 \pm 1.9$ bacteria cell $^{-1}$, respectively, whereas the adhesion of $P$. fluorescens was quite similar for the two strains with $10.6 \pm 0.5$ or
$18.1 \pm 1.9$ bacteria cell ${ }^{-1}$ and $8.2 \pm 0.6$ or $19.8 \pm 2$ bacteria cell ${ }^{-1}$ for MF37 and MFN1032, respectively.

The same experiment using HT-29 cells showed that the binding index of $P$. aeruginosa $\mathrm{PAO} 1$ remained the highest $\left(7.1 \pm 0.8\right.$ or $10.1 \pm 1.0$ bacteria cell $\left.^{-1}\right)$ but the index of P. fluorescens MFN1032 (4.3 \pm 0.6 or $8.3 \pm 1.6$ bacteria cell $\left.{ }^{-1}\right)$ was significantly higher than that of $\operatorname{MF37}\left(1.4 \pm 0.2\right.$ or $2.3 \pm 0.5$ bacteria cell $\left.^{-1}\right)$.

\section{Cytotoxicity assay}

The cytotoxic effect of Pseudomonas strains on Caco-2/ TC7 and HT-29 cells was determined by quantification of lactate dehydrogenase (LDH) released in culture medium (Figure 2).

P. fluorescens MF37 exhibited the lowest cytotoxic activity (expressed as \% of maximal LDH release) with only $7.8 \pm 1.9 \%$ (at $10^{6} \mathrm{CFU} \mathrm{ml}^{-1}$ ) or $30 \pm 16.4 \%$ (at $10^{8}$ $\mathrm{CFU} \mathrm{ml}{ }^{-1}$ ) of cell lysis after $24 \mathrm{~h}$ of infection on Caco-2/ TC7 (Figure 2A) and $17.5 \pm 1.1 \%$ (at $10^{6} \mathrm{CFU} \mathrm{ml}^{-1}$ ) or $22 \pm 2.0 \%$ (at $10^{8} \mathrm{CFU} \mathrm{ml}^{-1}$ ) of cell lysis for HT-29 cells (Figure 2B). The cytotoxicity of MFN1032 was higher with $34 \pm 15.2 \%$ or $74.7 \pm 4.6 \%$ lysis for infection respectively with $10^{6}$ or $10^{8} \mathrm{CFU} \mathrm{ml}{ }^{-1}$ on Caco-2/TC7 and $33.2 \pm 1.5$ or $60.3 \pm 5.5 \%$ lysis after infection with $10^{6}$ or $10^{8} \mathrm{CFU} \mathrm{ml}{ }^{-1}$ respectively on HT-29. P. aeruginosa PAO1 led to a total lysis of Caco-2/TC7 at the two bacterial concentrations tested and on HT-29, with infection rates of $10^{6}$ or $10^{8} \mathrm{CFU} \mathrm{m}{ }^{-1}$, LDH release was $67.9 \pm 7.2 \%$ or $85.6 \pm 3.4 \%$ respectively. At the end of infection, Caco-2/TC7 and HT-29 cells were observed by light microscopy. Figure 3 shows the cell monolayers after infection with MOI of $100\left(10^{8} \mathrm{CFU} \mathrm{ml}^{-1}\right)$. When Caco-2/TC7 cells where infected with P. fluorescens MF37, a slight cell detachment was detectable while more cells were detaching after infection with MFN1032. Infection with $P$. aeruginosa PAO1 led to a complete disappearance of the organized Caco-2/TC7 and HT-29 monolayers.

\section{Induction of IL-8 secretion}

The bacterial proinflammatory effect was assessed by measuring IL-8 secretion. Compared to untreated cells, the three Pseudomonas strains induced significant stimulation of IL- 8 secretion in both Caco-2/TC7 (Figure 4A) and HT-29 cells (Figure 4B). Mean values of IL-8 on HT-29 and Caco-2 in response to P. fluorescens MF37 and MFN1032 were similar for these two strains and it is noteworthy that IL-8 secretion was significantly increased in HT-29 compared to Caco-2 cells.

\section{NF- $\kappa$ B and AP-1 activation in Caco-2 and HT-29 reporter cell lines}

To further explore the immuno-modulatory properties of $P$. fluorescens MFN1032, we tested the effects of this 




bacterium on NF- $\kappa$ B or AP-1 activation using Caco-2 and HT-29 reporter cell lines. We observed that $P$. aeruginosa PAO1 stimulated NF- $\kappa \mathrm{B}$ activity by 2.5 -fold

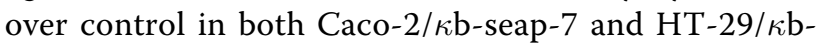
seap-25 reporter clones (Figure 5) while it had no effect on the AP-1 pathway (Figure 6). Interestingly, P. fluorescens MF37 and MFN1032 had an opposite effect. Indeed, none of these strains induced NF- $\kappa \mathrm{B}$ activation (Figure 5) whereas they both activated the AP-1 pathway by 2.2 -fold over control in Caco-2/ap1-luc-1 and HT29/ap1-luc-6 reporter clones (Figure 6).

\section{Discussion}

P. fluorescens is present at low level in the human gut and has been linked to Crohn's disease (CD) [7,8], however little is known about the potential interaction of this bacterium with the intestinal mucosa. In the present paper, we aimed at determining its potential to adhere to IEC, to induce cell cytotoxicity and trigger a proinflammatory response. We selected two strains, a classical psychrotrophic strain (MF37) and a recently characterized clinical strain adapted to grow at $37^{\circ} \mathrm{C}$ (MFN1032). The behaviour of these bacteria was compared to that of the opportunistic pathogen $P$. aeruginosa.

Since adhesion and cytotoxicity to IECs are crucial events in the infection process, the three strains were tested on two epithelial cell lines. Except for adhesion, the two IECs models used in this study gave similar responses to the three strains of Pseudomonas. Indeed, a dose dependent adhesion of bacteria to Caco-2/TC7 and HT-29 cells was observed with the greatest effect obtained with the opportunistic pathogen

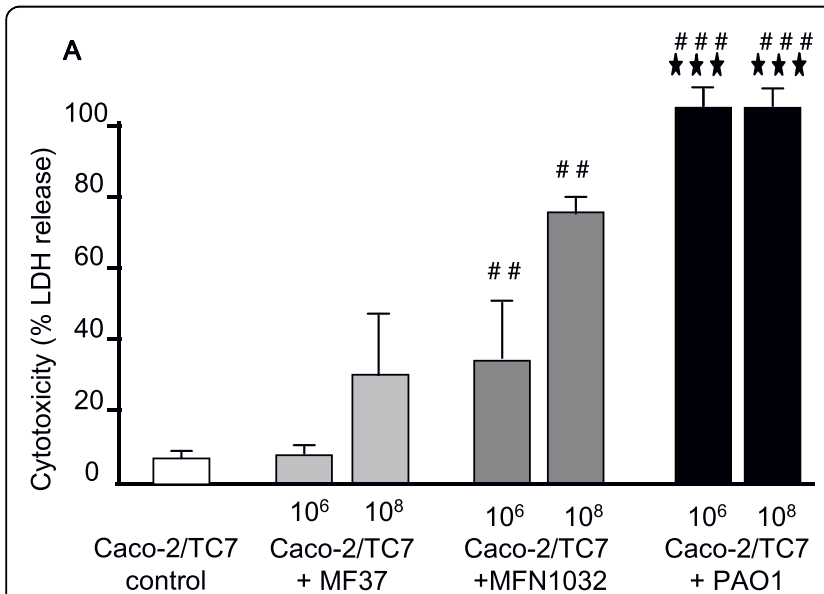

B

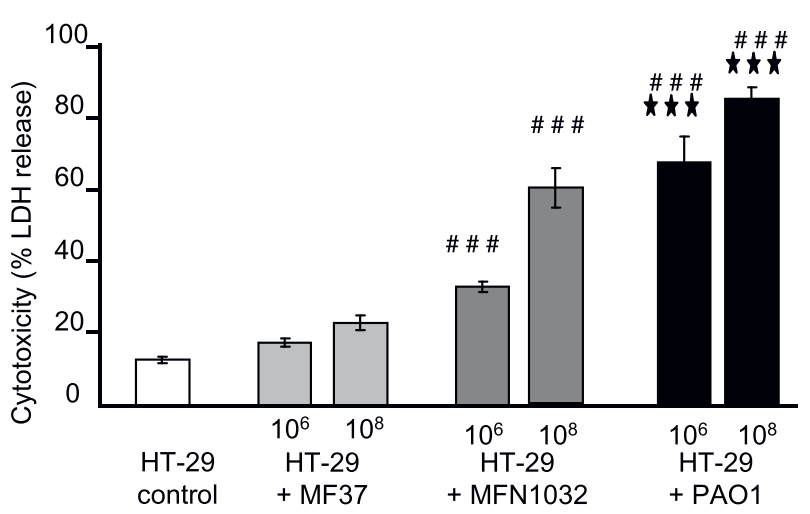

Figure 2 Cytotoxic effects of $P$. fluorescens MF37, P. fluorescens MFN1032 and $P$. aeruginosa PAO1 on Caco-2/TC7 (A) and HT-29 (B) cells. Cytotoxicity was determined by LDH release assay. Results were calculated as the mean values $( \pm \mathrm{SEM})$ of three independent experiments. For each dosis, \# \# $P<0.01$ versus MF37, \#\# \# $P<0.001$ versus MF37, *** $P<0.001$ versus MFN1032. 


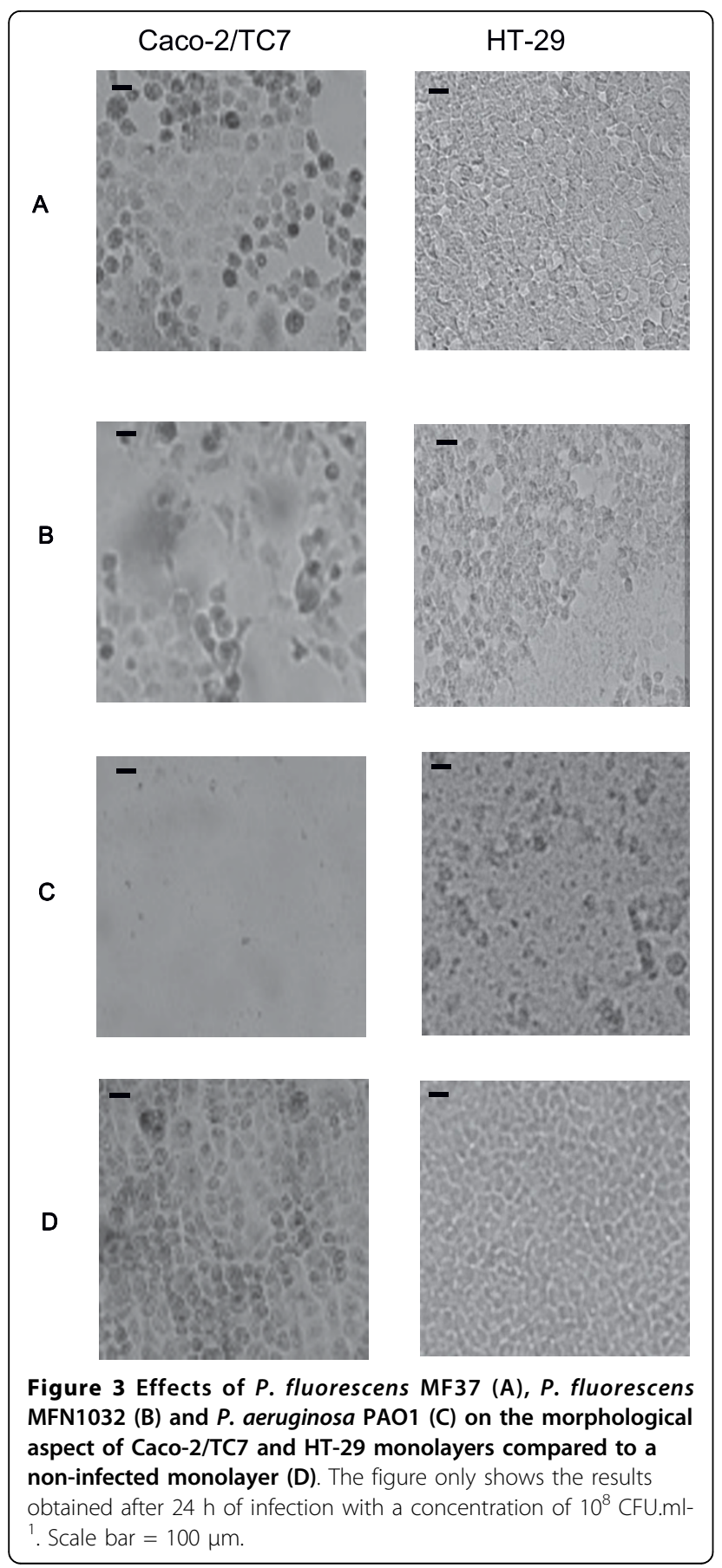

$P$. aeruginosa. It is noteworthy that, compared to the psychrotrophic strain MF37, the clinical strain P. fluorescens MFN1032, which is adapted to develop at $37^{\circ} \mathrm{C}$ displayed statistically significant higher adhesion potential to HT-29 but not to Caco-2/TC7 cells. This observation suggests that the clinical strain may express a greater diversity of adhesion factors than MF37 and could explain, at least in part, the higher cytotoxicity effect of MFN1032.

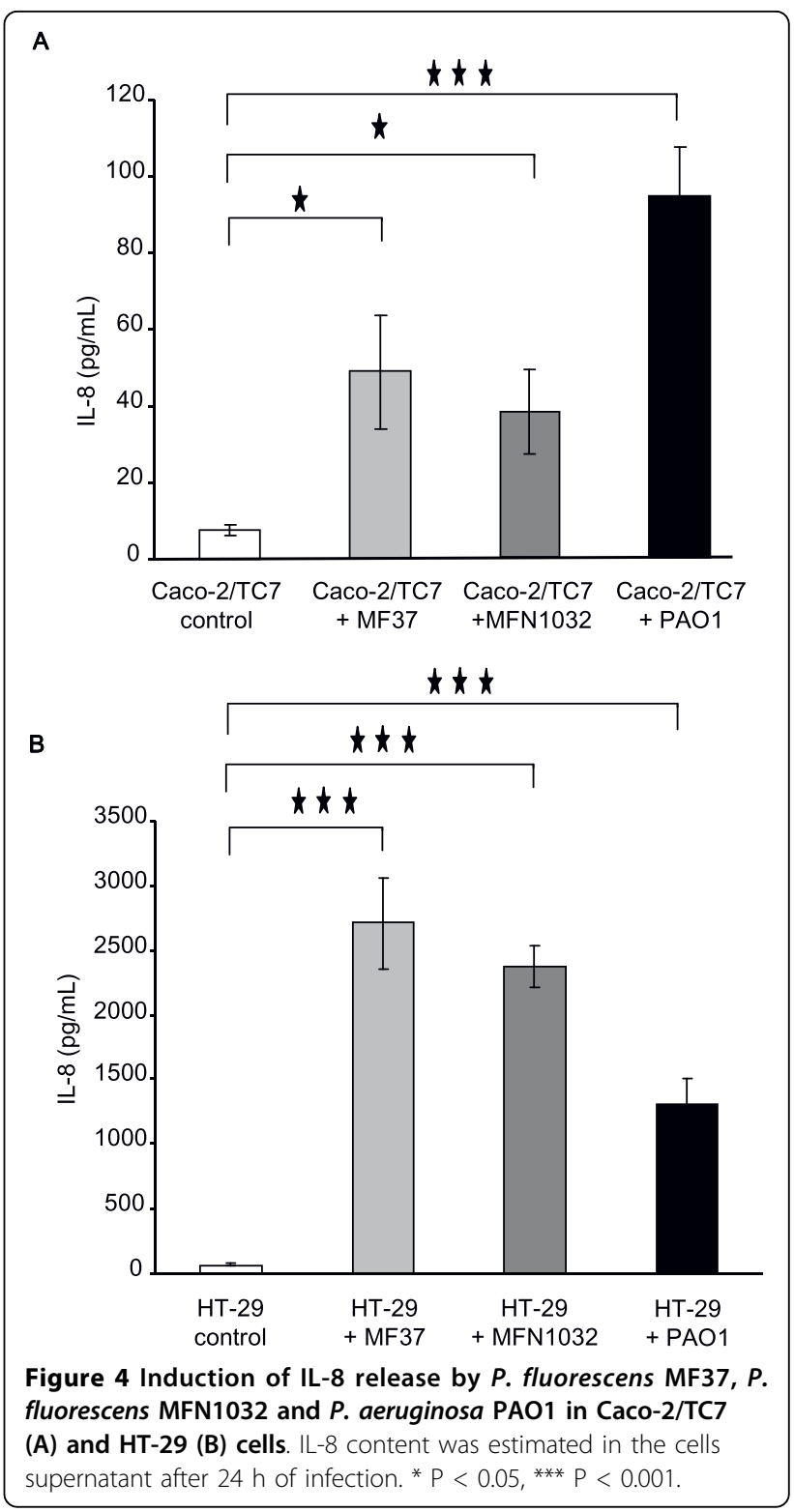

Although differences exist between surface proteins expressed by Caco-2/TC7 and HT-29 cell lines in comparison to normal human IECs, our results support the hypothesis that $P$. fluorescens should be able to colonize the intestinal mucosa. Pseudomonad are rarely searched for and detected as fecal bacteria, and are usually considered as a sub-dominant population [22]. In addition, there is now ample evidence that the circulating bacterial population in the intestinal lumen is very different from the resident microbiota that comes in contact with the apical surface of the enterocytes and is tightly associated to the mucus/glycocalyx layer [23,24]. For an aerobic bacterium such as $P$. fluorescens, the best ecological niche should be at the vicinity of the epithelium, where oxygen concentration is the highest in the 



Figure 5 Effects of $P$. fluorescens MF37, P. fluorescens MFN1032 and P. aeruginosa PAO1 on Caco-2/ $/$ b-seap-7 and HT-29/ $\kappa$ b-seap-25 cells expressing an $\mathbf{N F}-\kappa \mathbf{B} / \mathrm{SEAP}$ reporter system. The relative NF- $\kappa \mathrm{B}$ activation corresponding to SEAP activity is expressed in comparison to the activity measured in untreated control cells. IL-1 $\beta$ was used as positive control of NF- $\kappa$ B activation. ns: not significant, ${ }^{* * *} P<0.001$.

intestinal environment [25]. This is supported by the evidence showing that the $P$. fluorescens-specific I2 antigen sequence is systematically detected in ileal mucosa samples [7]. Moreover, in CD patients, there is a positive correlation between blood level of circulating antiI2 antibodies and the severity of the disease [8] suggesting that the I2-producing bacteria, i.e. P. fluorescens, are in close contact with enterocytes and could contribute to $\mathrm{CD}$ pathogenesis.

The LDH release assay showed that the cytotoxicity of P. fluorescens on Caco-2/TC7 and HT-29 cells is lower than that of $P$. aeruginosa. This limited virulence of the P. fluorescens strains seems to be normal for a species that should be a resident in the intestine whereas $P$. aeruginosa is typically an opportunistic pathogen only detected in case of declared infection [26]. This hypothesis is also in agreement with the hierarchy of the cytotoxic activity of the two tested strains of $P$. fluorescens, the clinical strain MFN1032 being more virulent than the environmental and psychrotrophic strain MF37. Bacterial cytotoxicity is a highly complex phenomenon combining the virulence of the prokaryote and the intrinsic sensitivity of the eukaryotic cell. In opposition to the present results, Chapalain et al found that the cytotoxic activity on glial cells was higher for $P$. fluorescens MF37 than MFN1032 [4]. These observations are in agreement with the work of Picot et al showing that in the case of $P$. fluorescens, the necrotic and apoptotic activities are not simply correlated to the adhesion potential of the strain [27].

In contrast to $P$. aeruginosa, the proinflammatory effect of $P$. fluorescens strains has not been elucidated.

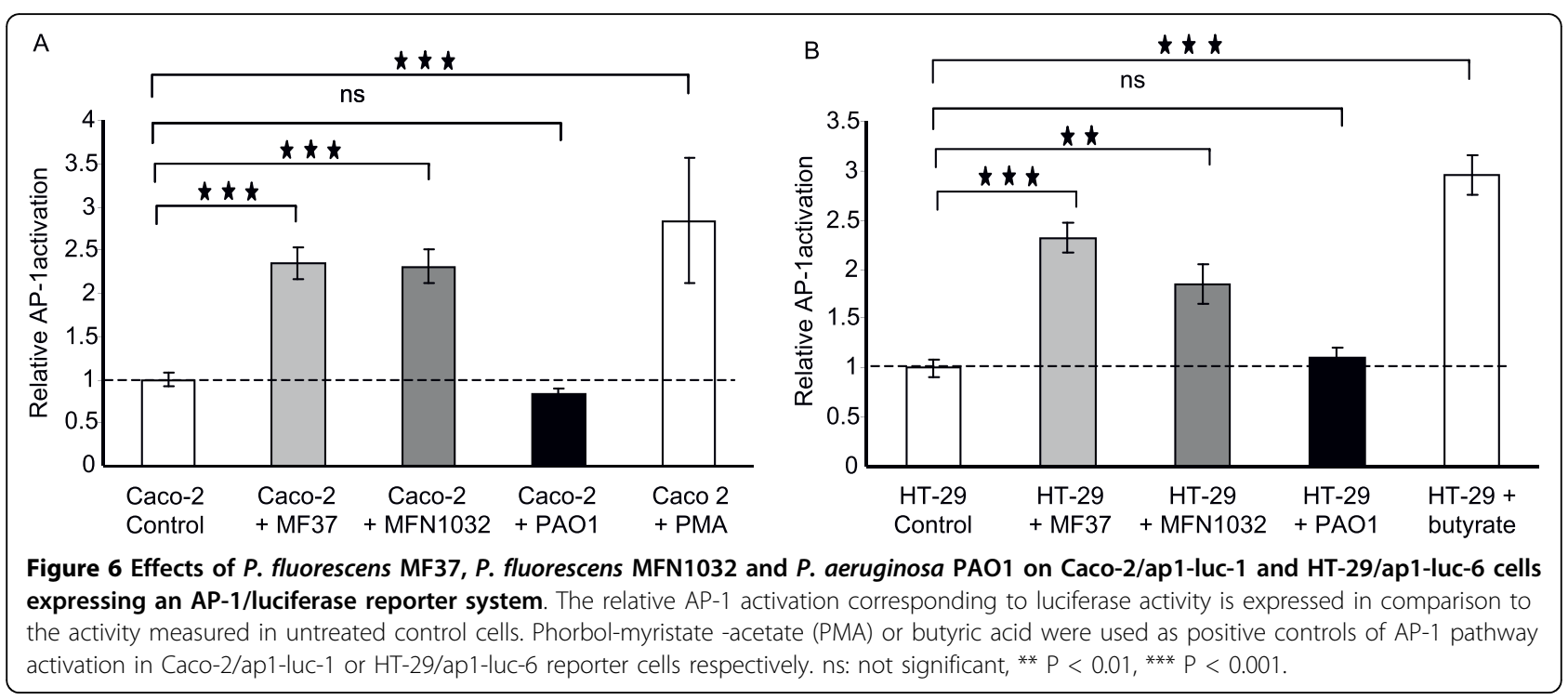


In this study, we demonstrated that similarly to $P$. aeruginosa, P. fluorescens MFN1032 and MF37 exerted a direct proinflammatory effect on IECs as demonstrated by induction of IL-8 secretion. The homogenous proinflammatory response of IECs induced by the two P. fluorescens strains studied suggests a link between the proinflammatory properties and a common pathogenic factor of these strains. IL-8 gene expression is regulated by several signaling pathways including mainly NF- $\kappa \mathrm{B}$ and AP-1 transcription factors. Previous studies have shown that $P$. aeruginosa activates NF- $\kappa \mathrm{B}$ in mouse monocyte/macrophage cell line [28] and MAPK signaling pathways in lung epithelial cells [29], which in turn leads to the production of proinflammatory cytokines, such as IL-6, IL-8, and TNF- $\alpha$ (tumor necrosis factor alpha). In our study, the two P. fluorescens strains failed to activate the NF- $\kappa \mathrm{B}$ pathway in contrast to $P$. aeruginosa, however the two strains were able to activate AP1 signaling, suggesting that the proinflammatory effect of these bacteria in IECs is linked to the activation of MAPK signaling pathways. The MAPK form a group of three pathways, including extracellular signal-regulated protein kinases (ERK1/2) and two stress-activated protein kinases designated p38 and JNK (c-jun N-terminal kinase) [30]. The activation of MAPK has been reported to be involved in response to infection by invasive bacteria, such as Salmonella enterica serovar typhimurium or Listeria monocytogenes, in IECs [31,32] or in macrophages [33]. Moreover, it has been shown that enteroadherent Escherichia coli activate this pathway and both bacterial attachment and secreted proteins might be implicated in cytokine responses [34]. P. aeruginosa as well as $P$. fluorescens contain multiple cell surface factors, including flagellin, pili, LPS, type III-mediated toxin secretion and quorum-sensing molecules which could interact with distinct epithelial membrane proteins, such as asialylated glycolipid receptors, toll like receptors (TLRs), or combinations of these proteins $[28,35,36]$. We have shown that purified flagellin strongly activated NF$\kappa \mathrm{B}$ pathway in HT-29 and to a lower extent in Caco-2, whereas both cell lines poorly responded to LPS (Lakhdari et al, submitted manuscript). In contrast, purified flagellin and LPS do not activated the AP-1 pathway in the two cell lines (data not shown). Thus, we can conclude that $P$. fluorescens activated AP-1 pathway in Caco2 and HT-29 independently of flagellin and LPS expression. Further investigations will be needed to identify the exact nature and function of $P$. fluorescens compounds responsible for MAPK activation in IECs.

\section{Conclusions}

P. fluorescens MFN1032, P. fluorescens MF37 and P. aeruginosa PAO1 were found to adhere to Caco-2/TC7 and HT-29 cells and the cytotoxicity towards these cell lines was higher for the clinical strain MFN1032 than for MF37. We showed that the two strains of $P$. fluorescens induced IL- 8 secretion by Caco-2/TC7 and HT-29 cells via the AP-1 signaling pathway whereas $P$. aeruginosa PAO1 potentially used the NF- $\kappa \mathrm{B}$ pathway. To our knowledge, this work is the first to demonstrate the interaction and the proinflammatory potential of P. fluorescens on IECs.

\section{Methods}

\section{Cell culture}

The human colon adenocarcinoma cell lines Caco-2/TC7 [37] and HT-29 were used between passages 10 and 35 . Caco-2/TC7 cells were grown in Dulbecco's modified Eagle Minimal Essential Medium (Sigma) containing 20\% foetal calf serum (FCS) supplemented with $2 \mathrm{mM}$ of L-glutamine, $100 \mathrm{U} \mathrm{ml}^{-1}$ each of penicillin and streptomycin and $1 \%$ non-essential amino acids at $37^{\circ} \mathrm{C}$ with $5 \% \mathrm{CO}_{2}$. HT-29 cells were grown in Dulbecco's modified Eagle Minimal Essential Medium (Sigma) containing 10\% FCS supplemented with $2 \mathrm{mM}$ of L-glutamine, $100 \mathrm{U} \mathrm{ml}^{-1}$ each of penicillin and streptomycin at $37^{\circ} \mathrm{C}$ with $5 \% \mathrm{CO}_{2}$.

\section{Bacterial strains and culture conditions}

P. fluorescens MF37 is a rifampicin-resistant natural mutant of the strain MF0 (Biovar V), originally identified in crude milk [38]. P. fluorescens MFN1032, is a clinical biovar I strain collected in a hospital of HauteNormandie (France) [4]. P. aeruginosa PAO1 was obtained from an international collection. Bacteria were grown overnight in ordinary nutrient broth (Merck) at $28^{\circ} \mathrm{C}$ for the two strains of $P$. fluorescens and at $37^{\circ} \mathrm{C}$ for $P$. aeruginosa $\mathrm{PAO} 1$. For adhesion and cytotoxicity assays, bacteria in stationary phase were harvested by centrifugation $\left(5000 \times g, 5 \mathrm{~min}, 20^{\circ} \mathrm{C}\right)$ and resuspended in antibiotic-free and serum-free cell culture media at densities of $10^{6}$ and $10^{8} \mathrm{CFU} \mathrm{ml}^{-1}$, corresponding to a multiplicity of infection (MOI) of 1 and 100 respectively.

\section{Adhesion assay}

For adhesion assays, Caco-2/TC7 and HT-29 cells were seeded at a concentration of $1 \times 10^{5}$ cells ml $^{-1}$ on coverslips coated with $50 \mu \mathrm{g} \mathrm{ml}^{-1}$ poly-L-lysine and used at $80 \%$ confluence as recommended by Li et al [39]. Cells were incubated for $5 \mathrm{~h}$ with $1 \mathrm{ml}$ of the bacterial suspensions. After incubation, the medium and non-adherent bacteria were removed by washing. Then, the coverslips were fixed with methanol (10 min), stained with Giemsa solution (20 min) and observed using an Axiovert S100TM light microscope (Zeiss). The adhesion index (mean number of bacteria adherent per cell) was determined by direct counting on a minimum of 100 cells following the technique of Darfeuille-Michaud et al [40]. 


\section{Cytotoxicity assay}

Confluent Caco-2/TC7 and HT-29 cells cultivated in 24well culture plates were infected for $24 \mathrm{~h}$ with $1 \mathrm{ml}$ of the bacterial suspensions. At the end of incubation, lactate dehydrogenase (LDH) present in the supernatant was measured in each well using the Cytotox $96^{\mathrm{R}}$ enzymatic assay (Promega). LDH is a stable cytosolic enzyme released by eukaryotic cells and an overall indicator of necrosis. Caco-2/TC7 and HT-29 cells exposed to Triton $\mathrm{X} 100(0.9 \%)$ were used as a control of total release (100\% LDH release). The background level (0\% LDH release) was determined with serum free culture medium. The percentage of cytotoxicity was calculated following the manufacturer's instructions.

\section{IL-8 ELISA}

IL-8 assays were performed on confluent Caco-2/TC7 and HT-29 cells monolayers grown in 24-well culture plates. After $24 \mathrm{~h}$ of infection with the bacterial suspensions (MOI of 100), immunoreactive IL-8 protein levels in cell culture supernatant were quantified using an ELISA Quantikine kit (R\&D systems) according to the manufacturer's protocol.

\section{Construction of stable NF- $\kappa$ B and AP-1 reporter cells}

The NF- $\kappa$ B reporter clones Caco- $2 / \kappa$ b-seap-7 and HT$29 / \kappa b$-seap- 25 were obtained after a stable transfection of parental cells with the reporter plasmid pNiFty2SEAP (Invivogen), which contains SEAP (secreted alkaline phosphatase) as reporter gene downstream of five repeats of the NF- $\kappa \mathrm{B}$ binding consensus.

The AP-1 reporter clones Caco-2/ap1-luc-1 and HT29/ap1-luc-6 were obtained after a stable co-transfection of the reporter plasmid pAP-1-luc (Stratagen), which contains luciferase as reporter gene downstream of seven repeats of the AP-1 binding consensus, together with pTK-Hyg (Clonetech) a hygromycine-based selection vector. Transfection of HT-29 was performed by lipofection using TFX-50 (Promega) according to the manufacturer's instructions while Caco- 2 cells were transfected using the Amaxa Nucleofector system (Lonza).

\section{Analysis of NF- $\kappa$ B and AP-1 activation}

For each experiment, reporter cells were seeded at 50 000 cells per well, into 96-well plates and pre-incubated 24 hours before adding live bacteria at an MOI of 100 .

For NF- $\kappa$ B activation assays, Caco- $2 / \kappa \mathrm{b}-$ seap -7 and HT-29/ $/$ b-seap-25 cells were incubated with live bacteria for 8 hours and IL-1 $\beta(10 \mathrm{ng} / \mathrm{ml})$ was used as a positive control. SEAP activity in the supernatant was measured using the Quanti-Blue reagent (Invivogen) using the manufacturer's protocol and quantified as OD at $655 \mathrm{~nm}$.
For AP-1 activation assays, cells were incubated for 12 $\mathrm{h}$ with live bacteria. Phorbol-myristate -acetate (PMA, 1 $\mu \mathrm{M})$ or butyric acid $(2 \mathrm{mM})$ was used as a positive control for Caco-2/ap1-luc-1 or HT-29/ap1-luc-6 reporter cells respectively. Luciferase activity was measured using the ONE-Glo ${ }^{\mathrm{m}}$. Luciferase Assay System (Promega) according to the manufacturer's instructions and quantified as relative luminescence units (RLU).

All measurements were performed using a microplate reader (Infinite 200, Tecan).

\section{Statistical analysis}

Data are expressed as a mean \pm standard error (SEM) calculated over three independent experiments performed in triplicate. Analysis of statistical significance were performed by ANOVA with Bonferroni post hoc test (adhesion and cytotoxicity assays) or Student's $t$-test (IL-8 secretion, NF- $\kappa$ B and AP-1 activation assays)

\section{Acknowledgements}

This work was supported by a BRI grant (Bourse Régionale Industrielle) from the Région Haute-Normandie and BIOGALENYS. OL is supported by the European Community's Seventh Framework Programme (FP7/2007-2013): MetaHIT, grant agreement HEALTH-F4-2007-201052. We thank Mihai Covasa and Christine Farmer for revising the English manuscript.

\section{Author details}

'LMDF-SME, Laboratoire de Microbiologie du Froid-Signaux et MicroEnvironnement, UPRES EA 4312, 55 rue Saint Germain, 27000 Evreux, France. ${ }^{2}$ BIOGALENYS, 9 Rue de Pacy, 27930 Miserey, France. ${ }^{3}$ INRA, UMR 1319 MICALIS, Domaine de Vilvert, F-78352 Jouy-en-Josas, France.

\section{Authors' contributions}

AM carried out most experiments and analyzed most of the data. NC wrote the manuscript, participated in the design of the study and analyzed most of the data. MG carried out the IL-8 ELISA assay. OL carried out the construction of NF- $\kappa$ B reporter cells. KR carried out the construction of AP-1 reporter cells. JD and $\mathrm{HB}$ participated in the design of the construction of $\mathrm{NF}-\kappa \mathrm{B}$ and AP-1 reporter cells and help to draft the manuscript. PS and NO were involved in the design of the study. MF participated in the design of the study and writing of the manuscript, AG performed the statistical analysis. All authors read and approved the final manuscript.

Received: 21 May 2010 Accepted: 10 August 2010 Published: 10 August 2010

\section{References}

1. Hirakata $Y$, Izumikawa K, Yamaguchi T, Igimi S, Furuya N, Maesaki S, Tomono K, Yamada Y, Kohno S, Yamaguchi K, et al: Adherence to and penetration of human intestinal Caco-2 epithelial cell monolayers by Pseudomonas aeruginosa. Infect Immun 1998, 66(4):1748-1751.

2. Plotkowski MC, de Bentzmann S, Pereira SH, Zahm JM, Bajolet-Laudinat O, Roger P, Puchelle E: Pseudomonas aeruginosa internalization by human epithelial respiratory cells depends on cell differentiation, polarity, and junctional complex integrity. Am J Respir Cell Mol Biol 1999, 20(5):880-890.

3. Zaborina O, Kohler JE, Wang Y, Bethel C, Shevchenko O, Wu L, Turner JR, Alverdy JC: Identification of multi-drug resistant Pseudomonas aeruginosa clinical isolates that are highly disruptive to the intestinal epithelial barrier. Ann Clin Microbiol Antimicrob 2006, 5:14.

4. Chapalain A, Rossignol G, Lesouhaitier O, Merieau A, Gruffaz C, Guerillon J, Meyer JM, Orange N, Feuilloley MG: Comparative study of 7 fluorescent pseudomonad clinical isolates. Can J Microbiol 2008, 54(1):19-27. 
5. Rajmohan S, Dodd CE, Waites WM: Enzymes from isolates of Pseudomonas fluorescens involved in food spoilage. J Appl Microbiol 2002, 93(2):205-213

6. Wei B, Huang T, Dalwadi H, Sutton CL, Bruckner D, Braun J: Pseudomonas fluorescens encodes the Crohn's disease-associated 12 sequence and Tcell superantigen. Infect Immun 2002, 70(12):6567-6575.

7. Sutton CL, Kim J, Yamane A, Dalwadi H, Wei B, Landers C, Targan SR, Braun J: Identification of a novel bacterial sequence associated with Crohn's disease. Gastroenterology 2000, 119(1):23-31.

8. Dalwadi H, Wei B, Kronenberg M, Sutton CL, Braun J: The Crohn's diseaseassociated bacterial protein $\mathrm{I} 2$ is a novel enteric $\mathrm{t}$ cell superantigen. Immunity 2001, 15(1):149-158.

9. Eckmann L, Kagnoff MF, Fierer J: Epithelial cells secrete the chemokine interleukin-8 in response to bacterial entry. Infect Immun 1993, 61(11):4569-4574.

10. McCormick BA, Miller SI, Carnes D, Madara JL: Transepithelial signaling to neutrophils by salmonellae: a novel virulence mechanism for gastroenteritis. Infect Immun 1995, 63(6):2302-2309.

11. Savkovic SD, Koutsouris A, Hecht G: Attachment of a noninvasive enteric pathogen, enteropathogenic Escherichia coli, to cultured human intestinal epithelial monolayers induces transmigration of neutrophils. Infect Immun 1996, 64(11):4480-4487.

12. Mukaida N, Okamoto S, Ishikawa $Y$, Matsushima K: Molecular mechanism of interleukin-8 gene expression. J Leukoc Biol 1994, 56(5):554-558.

13. Karin M, Lin A: NF-kappaB at the crossroads of life and death. Nat Immunol 2002, 3(3):221-227.

14. Hayden MS, Ghosh S: Shared principles in NF-kappaB signaling. Cell 2008, 132(3):344-362.

15. Hayden MS, West AP, Ghosh S: NF-kappaB and the immune response. Oncogene 2006, 25(51):6758-6780.

16. Schreiber S, Nikolaus S, Hampe J: Activation of nuclear factor kappa B inflammatory bowel disease. Gut 1998, 42(4):477-484.

17. Davis RJ: The mitogen-activated protein kinase signal transduction pathway. J Biol Chem 1993, 268(20):14553-14556.

18. Davis RJ: Signal transduction by the JNK group of MAP kinases. Cell 2000, 103(2):239-252.

19. Chapalain A, Chevalier S, Orange N, Murillo L, Papadopoulos V, Feuilloley MG: Bacterial ortholog of mammalian translocator protein (TSPO) with virulence regulating activity. PLoS One 2009, 4(6):e6096.

20. Rossignol G, Merieau A, Guerillon J, Veron W, Lesouhaitier O, Feuilloley MG, Orange $\mathrm{N}$ : Involvement of a phospholipase $\mathrm{C}$ in the hemolytic activity of a clinical strain of Pseudomonas fluorescens. BMC Microbiol 2008, 8:189.

21. Sperandio D, Rossignol G, Guerillon J, Connil N, Orange N, Feuilloley MG, Merieau A: Cell-associated hemolysis activity in the clinical strain of Pseudomonas fluorescens MFN1032. BMC Microbiol 10:124

22. Matsuda K, Tsuji H, Asahara T, Kado Y, Nomoto K: Sensitive quantitative detection of commensal bacteria by rRNA-targeted reverse transcriptionPCR. Appl Environ Microbiol 2007, 73(1):32-39.

23. Eckburg PB, Bik EM, Bernstein CN, Purdom E, Dethlefsen L, Sargent M, Gill SR, Nelson KE, Relman DA: Diversity of the human intestinal microbial flora. Science 2005, 308(5728):1635-1638.

24. Lepage P, Seksik P, Sutren M, de la Cochetiere MF, Jian R, Marteau P, Dore J: Biodiversity of the mucosa-associated microbiota is stable along the distal digestive tract in healthy individuals and patients with IBD. Inflamm Bowel Dis 2005, 11(5):473-480.

25. Saldena TA, Saravi FD, Hwang HJ, Cincunegui LM, Carra GE: Oxygen diffusive barriers of rat distal colon: role of subepithelial tissue, mucosa, and mucus gel layer. Dig Dis Sci 2000, 45(11):2108-2114.

26. Horing E, Gopfert D, Schroter G, von Gaisberg U: Frequency and spectrum of microorganisms isolated from biopsy specimens in chronic colitis. Endoscopy 1991, 23(6):325-327.

27. Picot L, Mezghani-Abdelmoula S, Chevalier S, Merieau A, Lesouhaitier O, Guerillon J, Cazin L, Orange N, Feuilloley MG: Regulation of the cytotoxic effects of Pseudomonas fluorescens by growth temperature. Res Microbiol 2004, 155(1):39-46

28. Kim K, Kim YU, Koh BH, Hwang SS, Kim SH, Lepine F, Cho YH, Lee GR: HHQ and $\mathrm{PQS}$, two Pseudomonas aeruginosa quorum-sensing molecules, down-regulate the innate immune responses through the nuclear factor-kappaB pathway. Immunology 2009.

29. McMorran B, Town L, Costelloe E, Palmer J, Engel J, Hume D, Wainwright B: Effector ExoU from the type III secretion system is an important modulator of gene expression in lung epithelial cells in response to Pseudomonas aeruginosa infection. Infect Immun 2003, 71(10):6035-6044.

30. Robinson MJ, Cobb MH: Mitogen-activated protein kinase pathways. Curr Opin Cell Biol 1997, 9(2):180-186.

31. Hobbie S, Chen LM, Davis RJ, Galan JE: Involvement of mitogen-activated protein kinase pathways in the nuclear responses and cytokine production induced by Salmonella typhimurium in cultured intestinal epithelial cells. J Immunol 1997, 159(11):5550-5559.

32. Tang P, Sutherland $C L$, Gold MR, Finlay BB: Listeria monocytogenes invasion of epithelial cells requires the MEK-1/ERK-2 mitogen-activated protein kinase pathway. Infect Immun 1998, 66(3):1106-1112.

33. Schwan WR, Kugler S, Schuller S, Kopecko DJ, Goebel W: Detection and characterization by differential PCR of host eukaryotic cell genes differentially transcribed following uptake of intracellular bacteria. Infect Immun 1996, 64(1):91-99.

34. Dahan S, Busuttil V, Imbert V, Peyron JF, Rampal P, Czerucka D: Enterohemorrhagic Escherichia coli infection induces interleukin-8 production via activation of mitogen-activated protein kinases and the transcription factors NF-kappaB and AP-1 in T84 cells. Infect Immun 2002, 70(5):2304-2310

35. Ratner AJ, Bryan R, Weber A, Nguyen S, Barnes D, Pitt A, Gelber S, Cheung A, Prince A: Cystic fibrosis pathogens activate $\mathrm{Ca} 2+$-dependent mitogen-activated protein kinase signaling pathways in airway epithelial cells. J Biol Chem 2001, 276(22):19267-19275.

36. Zhang Z, Reenstra W, Weiner DJ, Louboutin JP, Wilson JM: The p38 mitogen-activated protein kinase signaling pathway is coupled to Tolllike receptor 5 to mediate gene regulation in response to Pseudomonas aeruginosa infection in human airway epithelial cells. Infect Immun 2007, 75(12):5985-5992.

37. Chantret I, Rodolosse A, Barbat A, Dussaulx E, Brot-Laroche E, Zweibaum A, Rousset M: Differential expression of sucrase-isomaltase in clones isolated from early and late passages of the cell line Caco-2: evidence for glucose-dependent negative regulation. J Cell Sci 1994, 107(Pt 1):213-225.

38. Burini JF, Gugi B, Merieau A, Guespin-Michel JF: Lipase and acidic phosphatase from the psychrotrophic bacterium Pseudomonas fluorescens: two enzymes whose synthesis is regulated by the growth temperature. FEMS Microbiol Lett 1994, 122(1-2):13-18.

39. Li XJ, Yue LY, Guan XF, Qiao SY: The adhesion of putative probiotic lactobacilli to cultured epithelial cells and porcine intestinal mucus. J Appl Microbiol 2008, 104(4):1082-1091.

40. Darfeuille-Michaud A, Aubel D, Chauviere G, Rich C, Bourges M, Servin A, Joly B: Adhesion of enterotoxigenic Escherichia coli to the human colon carcinoma cell line Caco-2 in culture. Infect Immun 1990, 58(4):893-902.

doi:10.1186/1471-2180-10-215

Cite this article as: Madi et al:: The clinical Pseudomonas fluorescens MFN1032 strain exerts a cytotoxic effect on epithelial intestinal cells and induces Interleukin-8 via the AP-1 signaling pathway. BMC Microbiology 2010 10:215.

\section{Submit your next manuscript to BioMed Central and take full advantage of:}

- Convenient online submission

- Thorough peer review

- No space constraints or color figure charges

- Immediate publication on acceptance

- Inclusion in PubMed, CAS, Scopus and Google Scholar

- Research which is freely available for redistribution
C Biomed Central 